\title{
The adjuvant effect of allopurinol with valsartan on the treatment of essential hypertension
}

\author{
Fakhir Y. Hussein \\ Department of Medicine, College of Medicine, University of Mosul, Mosul, Iraq. \\ Correspondence: Fakhir Y. Hussein. fakhiryousif1960@gmail.com.
}

(Ann Coll Med Mosul 2018; 40 (1): 36-40).

Received: $6^{\text {th }}$ Oct. 2013; Accepted: $19^{\text {th }}$ Mar. 2014.

\section{ABSTRACT}

Background: Hyperuricemia is thought to contribute to development of hypertension, an elevation of uric acid in hypertension could be a consequence of reduced renal function, or elevated renal vascular resistance.

Objective: This paper aims to evaluate the adjuvant effect of allopurinol on blood pressure in newly diagnosed essential hypertensive patients with hyperuricemia.

Design: Double-blind randomized controlled clinical trial.

Patients and methods: Sixty newly diagnosed essential hypertensive patients with hyperuricemia in private clinic were enrolled in the study. They were randomly divided into two equal groups, group 1 was put on valsartan and allopurinol therapy, and group 2 was given valsartan and placebo therapy. Both groups were followed for four weeks duration. Blood pressure and serum uric acid levels were measured in both groups, before and after therapy.

Results: The systolic and diastolic blood pressures showed a significant reduction in group 1 with a mean difference of $-24.20 \pm 2.00 \mathrm{mmHg}$, for systolic blood pressure and $-16.93 \pm 4.73 \mathrm{mmHg}$ for diastolic blood pressure. The reduction in serum uric acid was $-3.25 \pm 0.18$, while the patients group that received valsartan and placebo did not show the same improvement.

Conclusion: The administration of allopurinol had beneficial effect on blood pressure, and can be used as adjunctive therapy for patients with hypertension, particularly if they have coexistent hyperuricemia.

Keywords: Adjuvant effect, allopurinol, essential hypertension, valsartan.

$$
\begin{aligned}
& \text { التأثير المساند لعقار الالوبيورينول مع الفالسارتان في علاج إرثفاع ضغط الام الشرياني } \\
& \text { فرع الطب، كلية الطب، جامعة الموصل، حسين، الموصل، العراق }
\end{aligned}
$$

الخلقية: يساهم فرط حمض البولة في الدام في إرتفاع ضغط الدم الشرياني، قد يكون نتيجة لإنخفاض وظائف الكلى، أو إرتفاع المقاومة الوعائية الكلوية.

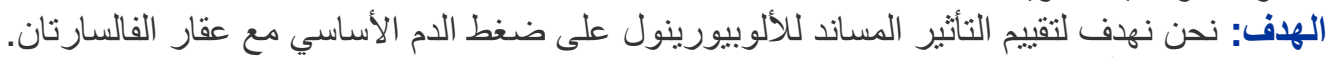

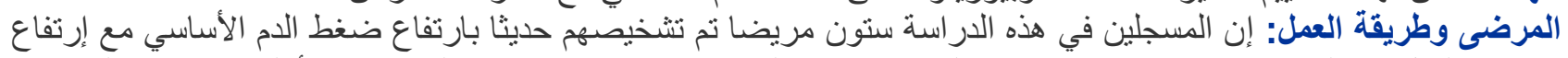

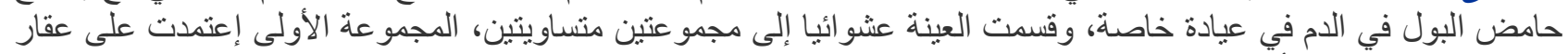

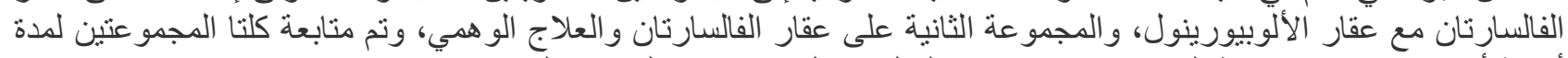

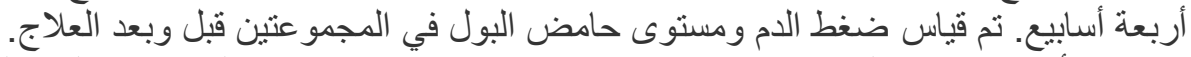

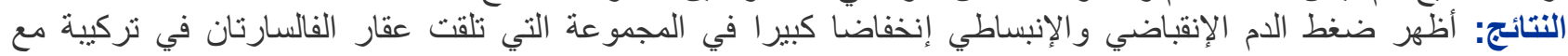

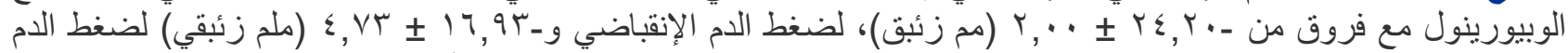

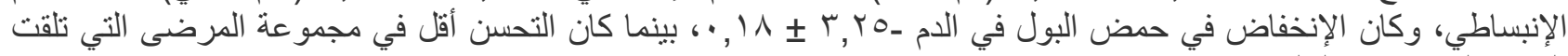

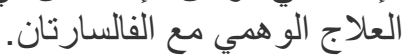
الإستنتاجات: بينت الدئ الدارة الحالية أن لعقار الألوبيورينول تأثير مفيد على ضغط الدم، ويمكن إستخدامها كعلاج مساعد في

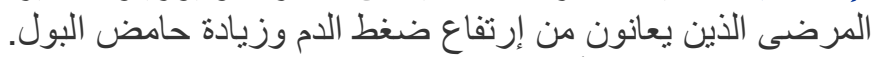

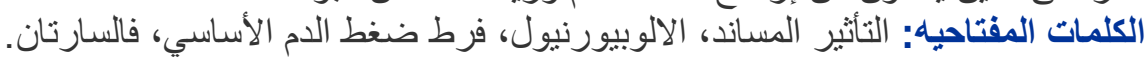




\section{INTRODUCTION}

ssential hypertension affects $25 \%$ of the world's population and is a major cause of stroke, congestive heart failure, end-stage renal disease, and myocardial infarction. ${ }^{1}$ Hypertension is a common disease, affecting $30 \%$ to $35 \%$ of adults, and is especially common in groups at high risk of cardiovascular disease. ${ }^{2}$ Hypertension is commonly associated with hyperuricemia. ${ }^{3}$ It has been noted that $20 \%-40 \%$ of patients with essential hypertension have hyperuricemia, and may represent an additional risk factor for the development of cardiovascular disease. ${ }^{4}$

Hyperuricemia is present in $25 \%$ of untreated hypertensive subjects, in $50 \%$ of subjects taking diuretics, and in $75 \%$ of subjects with malignant hypertension. ${ }^{5}$ Elevation of uric acid in hypertension could be a consequence of reduced renal function, the use of diuretics, the presence of hyperinsulinemia and oxidative stress, or elevated renal vascular resistance, which are commonly present in this condition. ${ }^{6}$ Urate level is routinely elevated in metabolic syndrome, because of high insulin levels, which decrease urate excretion, and it is unclear whether lowering urate levels will ameliorate any of the clinical features of this syndrome. $^{7}$

Despite a large number of safe and effective antihypertensive agents and useful lifestyle modification measures, optimal blood pressure (BP) control is attained in less than $40 \%$ of patients receiving therapy. ${ }^{1}$

Interestingly, raising uric acid levels in rats resulted in increased $\mathrm{BP}$ and the development of microvascular disease. ${ }^{8}$ The mechanism of hypertension uric acid-mediated reduction in endothelial nitric oxide levels, ${ }^{9,10}$ and stimulation of renin expression. ${ }^{11}$ Studies in humans have also correlated uric acid levels with both endothelial dysfunction $^{12,13}$ and elevated plasma renin activity. ${ }^{14,15} \quad$ Furthermore, several controlled clinical trials have reported that lowering uric acid with xanthine oxidase $(\mathrm{XO})$ inhibitors improves endothelial function under a variety of conditions. $^{16,18}$

Aim of the study: To evaluate the adjuvant effect of allopurinol with valsartan on blood pressure control in patients with essential hypertension.

\section{SUBJECTS AND METHODS}

The study had been approved from College of Medicine, university of Mosul. Administration and ethical approval was obtained from Nineveh Directorate of Health. Newly diagnosed cases of grade 2 hypertension defined as systolic BP $\geq 160$ $\mathrm{mmHg}$ and diastolic $\mathrm{Bp} \geq 100 \mathrm{mmHg}$, with serum uric acid level of $\geq 7 \mathrm{mg} / \mathrm{dL}^{19}$, with no evidence of target organ damage, had never been treated with antihypertensive medication for any indication were enrolled in this double-blind randomized control trial study during the period from June 2012 to July 2013. Patients with renal, cardiovascular and hepatic disease were excluded. Formal consent was obtained from all participants after discussing the purpose of the research with them and they were divided after gender stratification by simple random technique into two groups: each group consisted of 30 patients, group 1 received $80 \mathrm{mg}$ valsartan daily (using Diovan manufactured by Novartis), and allopurinol $100 \mathrm{mg}$ (using Zyloric manufactured by Glasgow, Smith, Klin) for 4 weeks, and group 2 received valsartan $100 \mathrm{mg}$ and placebo for 4 weeks duration. Both allopurinol and placebo were arranged in the form of unmarked capsules. Blood pressure and serum uric acid were measured before starting therapy and at the end of 4 weeks in both groups. Fasting serum glucose, lipid profile, serum urea, serum creatinine were measured in all patients in addition to general urine examination, electrocardiography and echocardiography.

Measurement of blood pressure: It was vital that the blood pressure readings were as accurate as possible, measurements were made to the nearest $2 \mathrm{mmHg}$, in the sitting position with the arm supported, after 5 minutes' rest; the cuff contained a bladder that encompasses at least two-thirds of the circumference of the arm.

Uric acid measurement was done, using standard kit manufactured by Randox Company following the instructions.

Independent t-test for two means was used in comparing between the two groups. Also paired ttest was used to analyze the difference of various parameters in each group. All values were expressed as mean \pm standard deviation (SD). 


\section{RESULTS}

Sixty patients were enrolled in this study, they were 44 males and 16 females as in Table 1.

Table 2 shows the patients characteristics of the studied groups before therapies. There were no differences between the groups regarding mean age and pretreatment systolic and diastolic blood pressure.

Table 3 shows the results of the comparison of the studied parameters of group 1 before and after therapy. There were a highly significant reduction in both systolic, diastolic BP, and uric acid $(\mathrm{P}=$ 0.001).

Table 4 demonstrates the results of the comparison of the studied parameters of group 2 before and after therapy. There were a highly significant reduction in both systolic and diastolic $B P$, and uric acid $(P=0.001)$.

Table 5 shows that the reduction in systolic and diastolic BP in group 1 was significantly superior to systolic and diastolic BP in group 2 with a mean differences of $-24.20 \pm 2.00$ systolic blood pressure and $-16.93 \pm 4.73$ for diastolic blood pressure in group 1 versus $-20.33 \pm 2.33$ for systolic BP, and $-9.84 \pm 0.84$ for diastolic BP in group 2 .

Table 1. Sex distribution of the studied groups.

\begin{tabular}{llccc}
\hline Groups & $\begin{array}{c}\text { Group 1 } \\
\text { (Hypertensive } \\
\text { patient on } \\
\text { Valsartan plus } \\
\text { Allopurinol) }\end{array}$ & \multicolumn{2}{c}{$\begin{array}{c}\text { Group 2 } \\
\text { (Hypertensive } \\
\text { patient on } \\
\text { Valsartan plus } \\
\text { placebo) }\end{array}$} \\
\hline Male & No. & $\%$ & No. & $\%$ \\
\hline Female & 7 & $70 \%$ & 21 & $65 \%$ \\
\hline Total & 30 & $100 \%$ & 30 & $100 \%$ \\
\hline
\end{tabular}

Table 2. Patient's characteristics of the studied groups.

\begin{tabular}{cccc}
\hline Parameter & $\begin{array}{c}\text { Group 1 } \\
\text { Mean } \pm \text { SD }\end{array}$ & $\begin{array}{c}\text { Group 2 } \\
\text { Mean } \pm \text { SD }\end{array}$ & $\begin{array}{c}\text { P- } \\
\text { value } \\
*\end{array}$ \\
\hline Age ( years) & $51.47 \pm 6.51$ & $52.3 \pm 0.6 .8$ & 0.631 \\
$\begin{array}{c}\text { Systolic BP } \\
\text { (mmHg) }\end{array}$ & $162.83 \pm 6.25$ & $167.3 \pm 9.41$ & 0.034 \\
$\begin{array}{c}\text { Diastolic BP } \\
\text { (mmHg) }\end{array}$ & $102.83 \pm 10.06$ & $102.67 \pm 9.71$ & 0.950 \\
$\begin{array}{c}\text { Uric acid } \\
\text { (mg/dL) }\end{array}$ & $7.43 \pm 0.84$ & $7.25 \pm 0.68$ & 0.365 \\
\hline *independent t-test for two means was used. & \\
\hline
\end{tabular}

*independent t-test for two means was used.
Table 3. The comparison of the studied parameters of the group 1 before and after the therapy.

\begin{tabular}{ccccc}
\hline Parameter & $\begin{array}{c}\text { Before } \\
\text { Mean } \pm \text { SD }\end{array}$ & $\begin{array}{c}\text { After } \\
\text { Mean } \pm \\
\text { SD }\end{array}$ & $\begin{array}{c}\text { Mean } \\
\text { difference }\end{array}$ & $\begin{array}{c}\text { P- } \\
\text { value* }\end{array}$ \\
\hline Systolic & $162.83 \pm$ & $138.5 \pm 7.78$ & $\begin{array}{l}-24.20 \\
\pm 2.00\end{array}$ & 0.001 \\
BP & 6.25 & & -16.93 & 0.001 \\
$(\mathrm{mmHg})$ & & & \pm 4.73 & \\
Diastolic & $102.83 \pm$ & $85.90 \pm 5.33$ & \\
BP & 10.06 & & $-3.25 \pm 0.18$ & 0.001 \\
$\begin{array}{c}\text { (mmHg) } \\
\text { Uric acid }\end{array}$ & $7.93 \pm 0.84$ & $4.70 \pm 0.61$ & & \\
(mg/dL) & &
\end{tabular}

Table 4. The comparison of the studied parameters of group 2 before and after the therapy.

\begin{tabular}{ccccc}
\hline Parameter & $\begin{array}{c}\text { Before } \\
\text { Mean } \pm \text { SD }\end{array}$ & $\begin{array}{c}\text { After } \\
\text { Mean } \pm \text { SD }\end{array}$ & $\begin{array}{c}\text { Mean } \\
\text { difference }\end{array}$ & $\begin{array}{c}\text { P- } \\
\text { value* }\end{array}$ \\
\hline Systolic & $167.3 \pm 9.41$ & $146.77 \pm 11.04$ & -20.33 & 0.001 \\
BP & \pm 2.33 & \\
(mmHg) & & & -11.84 & 0.001 \\
Diastolic & & & \\
BP & $102.67 \pm 9.71$ & $90.83 \pm 8.82$ & \pm 0.84 & \\
(mmHg) & & & $-0.73 \pm$ & 0.001 \\
Uric acid & $7.25 \pm 0.68$ & $6.52 \pm 0.52$ & 0.16 & \\
(mg/dL) & & & & \\
\hline "paired t-test for two means was used.
\end{tabular}

Table 5. The comparison of the mean difference of the systolic and diastolic BP of group 1 versus group 2 after therapies.

\begin{tabular}{cccc}
\hline Parameter & $\begin{array}{c}\text { valsartan and } \\
\text { allopurinol }\end{array}$ & $\begin{array}{c}\text { valsartan } \\
\text { and placebo }\end{array}$ & $\begin{array}{c}\text { P- value } \\
*\end{array}$ \\
\hline $\begin{array}{c}\text { Systolic BP } \\
(\mathrm{mmHg})\end{array}$ & $-24.20 \pm 2.00$ & $-20.33 \pm 2.33$ & 0.001 \\
$\begin{array}{c}\text { Diastolic } \\
\text { BP }\end{array}$ & $-16.93 \pm 4.73$ & $-9.84 \pm 0.84$ & 0.001 \\
$\begin{array}{c}\text { (mmHg) } \\
\text { (mpaired t-test for two means was used. }\end{array}$
\end{tabular}

\section{DISCUSSION}

Hypertension is associated with endothelial dysfunction. One major factor responsible for the impaired regulation of vascular tone is the increase in oxidative stress, leading to a premature breakdown of endothelium derived vasoactive nitric oxide. ${ }^{20}$

An important source for oxygen free radical production within the endothelium is the enzyme xanthine oxidoreductase. In its oxidase form this enzyme generates superoxide anion and hydrogen peroxide as byproducts. ${ }^{21}$ 
The present study was performed to evaluate the effect of allopurinol on a sample of hypertensive patients in Mosul population treated by valsartan. The study involved 60 patients were randomly allocated into two equal groups to rule out the effect of different variables as potential confounders.

The study clearly showed amarked improvment in the systolic and diastolic blood pressurs in the group who were taken valsartan $(80 \mathrm{mg})$ and allopurinol $(100 \mathrm{mg})$ daily for four weeks compaired to the group who were put on valsartan (80 $\mathrm{mg}$ ) alone.

A study done by Feig et al in 2004, ${ }^{2}$ in which adolescents with newly diagnosed essential hypertension were treated with allopurinol for one month, a reduction of serum uric acid level from a mean of $6.9 \mathrm{mg} / \mathrm{dL}$ to $3.3 \mathrm{mg} / \mathrm{dL}$ with $200 \mathrm{mg}$ of allopurinol twice daily significantly reduced casual blood pressure measurements, and led to normalization of blood pressure in 4 of 5 subjects.

A study done by Feig et al in 2008, ${ }^{6}$ using allopurinol $200 \mathrm{mg}$ twice daily for 4 weeks resulted in amean change in systolic BP for group who were on allopurinol of $-6.9 \mathrm{~mm} \mathrm{Hg}(95 \%$ confidence interval [Cl], -4.5 to $-9.3 \mathrm{mmHg}$ ) vs $-2.0 \mathrm{~mm} \mathrm{Hg}(95 \% \mathrm{Cl}, 0.3$ to-4.3 mm Hg; $\mathrm{P}=.009)$ for placebo, and the mean change in diastolic BP for allopurinol groupwas $-5.1 \mathrm{~mm} \mathrm{Hg}(95 \% \mathrm{Cl}$, -2.5 to $-7.8 \mathrm{~mm} \mathrm{Hg})$ vs $-2.4(95 \% \mathrm{Cl}, 0.2$ to -4.1 ; $\mathrm{P}=.05)$ for placebo group, and allopurinol treatment resulted in normal BP in 20 of 30 participants, including 19 of the $22(86 \%)$ whose uric acid levels were lowered to less than $5.0 \mathrm{mg} / \mathrm{dL}$. In contrast, only 1 of 30 participants became normotensive while receiving placebo during the study.

It has been shown that allopurinol treatment can improve forearm blood flow and endothelial dysfunction in patients with hypertension. ${ }^{22}$ In the context of reperfusion injury, it is understood that xanhhine oxide derived oxygen free radicals are a major contributor to impaired flow and tissue damage and that allopurinol may exert protective effects against these reperfusion injuries. ${ }^{23}$

Theoretically, inhibiting xanthine oxide with reducing serum uric acid may improve endothelial function and vasodilator capacity. A potent way to prevent xanthine oxide-generated free radicals in the clinical setting is to use the orally allopurinol. There is evidence to suggest that allopurinol may prevent free radical-induced tissue damage; for example, allopurinol decreases reperfusion injury during coronary artery bypass graft surgery ${ }^{24,25}$ and improves cardiorespiratory function in an animal transplantation model ${ }^{26}$ and in humans. ${ }^{27}$ Allopurinol may even speed up the repletion of high-energy phosphates during ischemia ${ }^{28}$. More recently, data have emerged to suggest that the acute intra-arterial infusion of oxypurinol, the active metabolite of allopurinol, may improve endothelial function in hypercholesterolemic humans. ${ }^{29}$ It is possible that part of the beneficial effect exerted by allopurinol may be attributed to its antioxidant properties. Allopurinol, by blocking xanthine oxide, will reduce superoxide anion and uric acid production by this enzymatic pathway. ${ }^{30}$

In experimental animals intrarenal renin expression has been shown to be mediated by uric acid,a clue to the mechanism by which allopurinol lowe $\mathrm{rBP}$, and this was the observation that systemic vascular resistance and plasma renin activity both decreased significantly with this drug. ${ }^{9}$

Toma et $a l,{ }^{31}$ reported that uric acid stimulates renin release via a macula densa dependent mechanism using an in vitro microperfused afferent arterioleglomerular preparation. Those studies showed that lowering uric acid may act at least in part, through reducing plasma renin activity.

In conclusion the study represent a potentially new therapeutic approach, that of control of a biochemical cause of hypertension, rather than nonspecifically lowering elevated BP. Although not representing a fully developed therapeutic strategythe study raises an alternative strategy that may prove to be more effective than currently available options.

\section{REFERENCES}

1. Sarafidis PA, Bakris GL. State of hypertension management in the United States: confluence of risk factors and the prevalence of resistant hypertension.J Clin Hypertens (Greenwich). 2008; 10(2):130-139.

2. Feig DI, Nakagawa T, Karumannchi SA et al. Hypothesis: Uric acid,nephron number, and the pathogenesis of essential hypertension. Kidney International, 2004; 66: 281-287.

3. Cannon PJ, Stason WB, Demartini FE, Sommers SC, Laragh $\mathrm{JH}$. Hyperuricemia in primary and renal hypertension .N Eng. J Med. 1966; 275(9):457- 464.

4. Trachtman $\mathrm{H}$, Valderrema E, Futterweit $\mathrm{S}$. Nephrotoxicity of allopurinol is enhanced in experimental hypertension. Hypertension 1991; 17: 194- 202. 
5. Johnson RJ, Segal MS, Srinivas T, et al. Essential hypertension, progressive renal disease, and uric acid: a pathogenetic link? J Am SocNephrol. 2005; 16(7):19091919.

6. Feig DI, Soletsky B, Johnson RJ. Effect of Allopurinol on blood pressure of adolescents with newly diagnosed essential hypertension. JAMA. 2008; 300:924-932.

7. Fields TR, Paget SA, Beary JF. Gout etiopathogenesis: Manual of Rheumatology and Outpatient Orthopedic Disorder $5^{\text {th }}$ edition. Philadelphia. 2006; 328-335.

8. Mazzali M, Hughes J, Kim YG, et al. Elevated uric acid increases blood pressure in the rat by a novel crystal-independent mechanism. Hypertension. 2001; 38:1101-1106.

9. Sanchez-Lozada LG, Tapia E, Lopez-Molina R, et al. Effects of acute and chronic L-arginine treatment in experimental hyperuricemia. Am J Physiology. 2007; 292(4):1238-1244.

10. Johnson RJ, Kang D, Feig D, et al. Is there a pathogenetic role for uric acid in hypertension and cardiovascular and renal disease? Hypertension .2003; 41:1183-1190.

11. Mazzali M, Kanellis J, Han L, et al. Hyperuricemia induces a primary renal arteriolopathy in rats. blood pressure-independent mechanism. Am J Physiol Renal Physiol. 2002; 282(6): 991-997.

12. Erdogan D, Gullu H, Caliskan M, et al. Relationship of serum uric acid to measures of endothelial function and atherosclerosis in healthy adults. Int $\mathrm{J}$ Clin Pract. 2005; 59(11):1276-1282.

13. Zoccali C, Maio R, Mallamaci F, Sesti G, Perticone $F$. Uric acid and endothelial dysfunction in essential hypertension. J Am SocNephrol. 2006; 17(5):1466-1471. 14. Gruskin AB. The adolescent with essential hypertension. Am J Kidney Dis. 1985; 6(2):86-90.

15. 15. Saito I, Saruta T, Kondo K, et al. Serum uric acid and the rennin angiotensin system in hypertension.J Am Geriatr Soc. 1978;26(6):241-247.

16. Doehner W, Schoene N, Rauchhaus M, et al. Effects of xanthine oxidase inhibition with allopurinol on endothelial function and peripheral blood flow in hyperuricemic patients with chronic heart failure: results from 2 placebo-controlled studies. Circulation, 2002; 105(22):2619-2624.

17. Mercuro G, Vitale C, Cerquetani E, et al. Effect of hyperuricemia upon endothelial function in patients at increased cardiovascular risk. Am J Cardiol. 2004; 94(7):932-935.

18. Farquharson CA, Butler $R$, Hill $A$, Belch $J J$, StruthersAD. Allopurinol improves endothelial dysfunction in chronic heart failure. Circulation, 2002; 106(2):221-226.
19. Crook MA. Clinical chemistry and metabolic medicine, $7^{\text {th }}$ edition, Holder Arnold.UK.2006;pp 301-307. 20. Cockcroft JR, Chowienczyk PJ, Benjamin N, Ritter JM. Preserved endothelium dependent vasodilatation in patients with essential hypertension. $\mathrm{N}$ Eng. J Med. 1994; 330: $1036-1040$.

21. Doehner W, Schoene N, Rauchhaus M et al. Effects of xanthine oxidase Inhibition with allopurinol on endothelial function and peripheral blood flow in hyperuricemic patients with chronic heart failure : results from 2 placebo-controlled studies. Circulation 2002, 105:2619-2624.

22. Butler R, Morris AD, Belch JJF, et al. Allopurinol normalizes endothelial dysfunction in Type 2 diabetics with mild hypertension. Hypertension 2000, 35:746-751 . 23. Alper AB,Chen $W, Y a u L$ et al, Childhood uric acid predicts adult blood pressure. Hypertension. 2005; 45(1): 34-38.

24. Selby JV, Friedman GD, Quesenberry CP. Precursors of essential hypertension: pulmonary function, heart rate, uric acid, serum cholesterol, and other serum chemistries. Am J Epidemiol. 1990;131(6): 1017-1027.

25. Gimpel JA, Lahpor JR, Vandermolen AJ, Damen $\mathrm{J}$, Hitchcock JF. Reduction of reperfusion injury of human myocardium by allopurinol: a clinical study. Free Radic Biol Med. 1995;19:251-255.

26. Qayumi AK, Godin DV, Jamieson WRE, Ko KM, Poostizadeh A. Correlation of red cell anti-oxidant status and heart-lung function in swine pre-treated with allopurinol. Transplantation. 1993;1:37- 43.

27. Coghlan JG, Flitter WD, Clutton SM, Panda R, Daly $\mathrm{R}$, Wright $\mathrm{G}$, Ilsley $\mathrm{CD}$, Slater TF. Allopurinol pretreatment improves postoperative recovery and reduces lipid-peroxidation in patients undergoing coronary artery bypass grafting. J Thorac Cardiovasc Surg. 1994;1:248 $-256$.

28. Pisarenko OI, Lakomkin VL, Studneva IM, Timochin AA, Kuzmin AL, Ruuge EK, Kapelko VI. Allopurinolenhanced post ischaemic recovery in the isolated rat heart involves repletion of high energy phosphates. Biochem Med Metab Biol. 1994;51:16 -26.

29. Cardillo C, Kilcoyne CM, Cannon RO III, Quyyumi AA, Panza JA. Xanthine oxidase inhibition with oxypurinol improves endothelial function in hypercholesterolemic but not in hypertensive patients. Hypertension. 1997;30:57- 83.

30. Laura G, Sanchez-Lozada, Tabia E et al. Mild hyperuricemia induces glomerular hypertension in normal rats. Am J Physiol Renal Physiol 2002; $283: 1105-1110$.

31. Toma I, Kang J, Meer E, Pet-Peterdi J. Uric acid triggers renin release via a macula dens dependent pathway. JAMA. 2008; 300:924-32. 